\title{
Variety Development Cost versus Variety Adoption in Major Cereals in Nepal
}

\author{
Hari K. Shrestha ${ }^{1}$, Hira K. Manandhar ${ }^{1}$, and Punya P. Regmi ${ }^{2}$ \\ ${ }^{1}$ Nepal Agricultural Research Council \\ Singhdurbar Plaza, Kathmandu \\ ${ }^{2}$ Institute of Agriculture and Animal Science \\ Rampur, Chitwan \\ e-mail: hkshrestha_1@yahoo.com
}

\begin{abstract}
This study was carried out to measure the research investment in major cereals, namely, rice, maize and wheat, and identify the general adoption status of their released varieties in Nepal. Financial resource use was derived from disaggregated expenditure whereas human resource use was approximated from full time equivalent (FTE) of researchers in each crop through questionnaire survey. Information regarding the farmers' adoption was collected through group interaction with extension staff in selected hill and Terai districts from each of five geographical regions of the country. The variety development cost was Rs. 38.1 million in maize, 15.8 million in wheat, and 14.6 million in rice during 2001-2010 at 2000/01price. Of the total FTE researchers, 35 in rice, 28 in wheat and 18 in maize were involved in various disciplines of the crop research whereas 8 FTE researchers were involved in breeding of each of the crops. Among the most common rice varieties, Khumal-4 was adopted in 55\% area in Kavre district, Radha-12 was adopted in 40\% area in Sunsari district and Radha-4 was adopted in 70\% area in Banke district in the main season. Indian hybrid maize was common in most of the Terai districts with maximum adoption in 95\% area in Bara district. Among the popular wheat varieties, Gautam was common in hill and Terai districts with the adoption range from 30 to $50 \%$ of total wheat area. Compared with maize and wheat, adoption of improved rice varieties was relatively low since high yielding and suitable rice varieties were still lacking for various domains.
\end{abstract}

Key words: adoption percent, disaggregated expenditure, full time equivalent (FTE), investment, variety development cost

\section{Introduction}

Rice, maize and wheat are Nepal's major cereal crops which have pivotal role in the country's food security and farmers' livelihood. Variety development program in these crops has played a crucial role in increasing food grain production over the years. Nepal Agricultural Research Council (NARC) has long time collaboration with international research organizations such as International Rice Research Institute (IRRI) and International Maize and Wheat Improvement Center (CIMMYT) and it has developed 55 varieties of rice, 32 varieties of wheat and 23 varieties of maize to date (NARC 2012). This study was carried out to evaluate the research investment in rice, maize and wheat, and identify the adoption status of their released varieties in the country. Higher adoption of the released varieties could properly justify the investment in variety development whereas low or no adoption may not justify such investment.

During the last 25 years, average farm yield of wheat increased from $1181 \mathrm{~kg} /$ ha to $2129 \mathrm{~kg} / \mathrm{ha}$ (80\%), from $1417 \mathrm{~kg} / \mathrm{ha}$ to $2119 \mathrm{~kg} / \mathrm{ha}$ (49\%) in maize, and from 1968 $\mathrm{kg} / \mathrm{ha}$ to $2716 \mathrm{~kg} / \mathrm{ha}$ (38\%) in rice (MoAC 2010). The reason behind the production increase may not be only the variety development but also the area expansion of the crops. Modern varieties could contribute in the area expansion of the crop due to higher productivity and profitability. Development of modern varieties had a synergistic effect in the area expansion of wheat in Nepal during 1960s as farmers were encouraged to cultivate wheat in more areas due to introduction of high yielding varieties (Morris et al. 1994). 
Nepal Journal of Science and Technology Vol. 13, No. 1 (2012) 7-15

\section{Methodology}

Investment analysis in variety development rested upon primary and secondary data on the allocation of financial and human resources in breeding and support activities. Time series data of the expenditure in each crop for ten years (2000/01 to 2009/10) was collected from the financial records of the research stations. To estimate the human resource use, information on the researchers' time spent in various aspects of crop research on a full time equivalent (FTE) basis was collected from 120 researchers through questionnaires. FTE was used as common unit of measurement of human resources involved in a particular sector, commodity, or discipline (Stads \& Shrestha 2006, Rahija et al. 2011). For instance, breeders spent their full time in variety development means that a breeder is equivalent to one FTE. In addition to the breeders, other researchers supported the variety development program through various disciplinary activities related to agronomy, soil science, entomology, plant pathology etc. A support researcher contributed in variety development activity with less than one FTE based on how much time he or she spent in such activity on a particular crop. The sum of time contributions of several support researchers may be equivalent to one FTE.

NARC has been involved in variety development of cereal crops with multi-location testing in various ecological sites. Therefore, cost related to variety development in all research stations was accounted. This study also considered the external research funds which were received by the research stations from international organizations for specific crops. The research stations also received genetic materials or breeding lines from the international research organizations for variety development purpose. However, this study has not accounted the cost involved in for developing breeding lines in those organizations from where the breeding materials were received. This is a limitation of this study.

Information on the adoption status of modern varieties of rice, maize and wheat was collected through group interviews with extension staff in purposively selected ten districts that represented various ecological and geographical regions during 2011. Group interview was carried out with the help of check list to collect the information at district level. The other survey methods like household interview might not be appropriate since survey village/sites generally do not represent the whole district because of large variation of climatic condition within the district. Variation of climatic condition is much prominent in hill districts due to altitude differences from river basin to high hills. Moreover, such household survey requires lot of time and man power. Most of the adoption studies which followed household survey in Nepal were confined in village or ward level. Among the selected five hilly districts, Dhankuta, Kavre, Parbat, Dailekh and Doti represent eastern hills, central hills, western hills, mid western hills and far western hills, respectively. Other five selected districts were Sunsari, Bara, Rupandehi, Banke and Kailali which represent eastern Terai, central Terai, western Terai, mid western Terai and far western Terai, respectively.

\section{Results and Discussion}

\section{Financial resource allocation}

The growth of research investment was erratic and inconsistent in rice, maize and wheat during last ten years. The overall research costs in all three commodities had declined in real term over the years (Table 1). During the first three years, higher investment was found in rice as compared to wheat and maize whereas this investment ratio was changed in the following years. The World Bank supported AREP had largely contributed in the research cost of rice and wheat during the period. During 2003/04-2007/

Table 1. Operational cost in rice, maize and wheat research (at 2000/01 price)

\begin{tabular}{l|l|l|l}
\hline Fiscal Year & \multicolumn{1}{|c|}{ Rice } & \multicolumn{1}{|c}{ Maize } & \multicolumn{1}{c}{ Wheat } \\
\hline $2000 / 2001$ & $10190(2446)$ & $2937(1351)$ & $7469(2539)$ \\
$2001 / 2002$ & $12737(3057)$ & $3547(1632)$ & $9020(3067)$ \\
$2002 / 2003$ & $5031(1207)$ & $1481(681)$ & $4563(1551)$ \\
$2003 / 2004$ & $4459(1070)$ & $15148(6968)$ & $3839(1305)$ \\
$2004 / 2005$ & $6069(1457)$ & $15396(7082)$ & $4069(1383)$ \\
$2005 / 2006$ & $3927(942)$ & $13670(6288)$ & $2704(919)$ \\
$2006 / 2007$ & $5199(1248)$ & $12880(5925)$ & $3663(1245)$ \\
$2007 / 2008$ & $5669(1361)$ & $14120(6495)$ & $4875(1658)$ \\
$2008 / 2009$ & $4030(967)$ & $1923(885)$ & $3658(1244)$ \\
$2009 / 2010$ & $3455(829)$ & $1731(796)$ & $2781(946)$ \\
\hline
\end{tabular}

Note: figures in parenthesis are the cost of variety development 
08, the investment in maize was higher due to financial support of Swiss Development Corporation (SDC) through Hill Maize Research Program (HMRP). It showed that research investment varied according to donor's support in a particular crop. In addition to this research cost, substantial amount of capital cost and administrative cost were involved which could not be disaggregated according to crops because most of the research stations dealt with multi commodities rather than single commodity.

During the last ten years, the total research cost in maize was the highest followed by rice and wheat (Fig. 1). Variety development was a major activity that consumed a substantial cost in the commodity research program. The total research cost was Rs. 82.8 million in maize, 60.8 million in rice and 46.6 million in wheat whereas variety development cost was Rs. 38.1 million (46\%) in maize, 14.6 million (24\%) in rice, and 15.8 million (34\%) in wheat during 2001-2010. This showed that the variety development cost was similar in rice and wheat but it was two and half times more in maize.

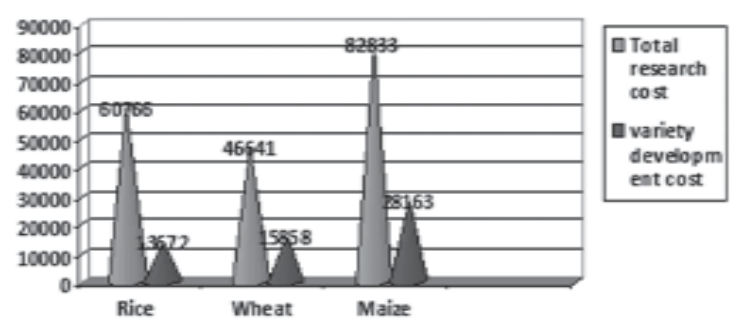

Fig. 1. Research investment (Rs. '000) at 2000/01 price

\section{Human resource allocation}

The least human resource was used in maize research although the research cost in this commodity was higher than in rice and wheat. On the basis of FTE, the researchers involved in rice, wheat, maize were 35,28 , and 18 respectively in the research system of the country (Table 2). Of the total FTE researchers, about 8 FTE were involved in breeding or variety development in each of rice, wheat and maize. Although similar numbers of FTEs were involved in each crop, breeding or variety development cost was $22 \%$ in rice, $31 \%$ in wheat and $41 \%$ in maize. For crop management research, 11 FTE in rice, 7 in wheat and 4 in maize were involved. It indicated that the major focus was variety development in maize and wheat whereas it was crop management in rice.

\section{Adoption status}

Technology adoption is determined by various factors which are directly and indirectly related to on-farm situation and farmers' socio-economic conditions. Empirical studies of technology adoption indicate that on-farm and farmer characteristics, and institutional variables influence the probability and rate of adoption (Feder et al. 1985, Bellon \& Taylor 1993, Doss 2006). However, our purpose in this study was to identify variety adoption status rather than to analyze the determinants of the variety adoption.

\section{Eastern hills}

Dhankuta district was the sample district for eastern hills where we collected the information of adopted varieties of rice, maize and wheat. Most of the modern varieties in this district were developed by national commodity research programs. However, a large area (40\%) of rice was still covered by traditional varieties having low yield potential. Radha-12 for rice, Manakamana-3 for maize, and Gautam and Annapurna-

Table 2. Full time equivalent (FTE) in cereals research across thematic area

\begin{tabular}{l|c|c|c|c|c|c}
\hline \multirow{2}{*}{ Thematic area } & \multicolumn{2}{|c|}{ Rice } & \multicolumn{2}{c}{ Wheat } & \multicolumn{2}{c}{ Maize } \\
\cline { 2 - 6 } & FTE & \% Share & FTE & \% Share & FTE & \% Share \\
\hline Breeding & 7.7 & 22 & 8.535 & 31 & 7.54 & 41 \\
Crop management & 11.0 & 32 & 7.53 & 27 & 3.75 & 21 \\
Plant protection & 2.4 & 7 & 3.85 & 14 & 4.1 & 22 \\
Soil science & 3.4 & 10 & 2.435 & 8 & 0.7 & 4 \\
Mechanization & 3.8 & 11 & 3.487 & 12 & 6.97 & 5 \\
Socio-economics & 6.0 & 17 & 1.658 & 6 & 0 & 0 \\
Environmental science & 0.4 & 1 & 0.51 & 2 & 10.26 & 100
\end{tabular}


Nepal Journal of Science and Technology Vol. 13, No. 1 (2012) 7-15

Table 3. Rice, maize and wheat varieties adopted in Dhankuta district, 2009/2011

\begin{tabular}{l|c|l|c|c|c}
\hline \multicolumn{2}{c|}{ Rice } & \multicolumn{2}{c}{ Maize } & \multicolumn{2}{c}{ Wheat } \\
\hline Variety & Area (\%) & Variety & Area (\%) & Variety & Area (\%) \\
\hline Khumal-4 & 12 & Manakamana-3 & 20 & Gautam & 30 \\
Radha-12 & 20 & Rampur Composite & 10 & NL 297 & 10 \\
Hardinath-1 & 18 & Deuti & 12 & Annapurna-4 & 30 \\
Bansdhan & 10 & Ganesh-1 & 15 & Bhrikuti & 15 \\
Traditional & 40 & Arun-2 & 12 & Annapurna-3 & 10 \\
& & Arun-1 & 8 & RR-21 & 5 \\
\hline Total & & Hybrid & 2 & & Total \\
\hline
\end{tabular}

4 for wheat were the major varieties adopted in this district (Table 3). In maize, traditional varieties had covered $21 \%$ area whereas in wheat, a small percentage of farmers were still growing an old variety, RR21 due to its drought resistance character although it was denotified as a rust susceptible variety.

\section{Eastern Terai}

Sunsari district was the representative district of eastern Terai. Radha-12, released in 1995 for eastern Terai, was the most popular rice variety which was adopted in $40 \%$ area. Indian rice varieties with different local names were also adopted in 35\% area. Witcombe et al. (2009) reported that Radha-12 was one of the widely grown varieties in Nepal's Terai. Timsina et al. (2012) also reported that Radha-12 was the most preferred and adopted variety among the improved varieties in Sunsari district. However, adoption status may be different from one district to another district as Gauchan and Pandey (2011) found Radha-11 as a dominant rice variety that was adopted in $23 \%$ of the total rice area in Siraha, a neighboring district of Sunsari. Among the wheat varieties, NL 297, released in 1985, was still a dominant variety adopted in $60 \%$ area whereas Gautam, released in 2004, was adopted only in 38\% area. In maize, Indian hybrids had covered $80 \%$ of total maize area whereas Rampur Composite (released in 1975) had covered rest of the area. The overall adoption status showed that modern varieties of rice and wheat were adopted in $98 \%$ area whereas those of maize varieties were adopted in $100 \%$ area (Table 4).

Table 4. Rice, maize and wheat varieties adopted in Sunsari district, 2009/2010

\begin{tabular}{l|c|l|l|l|c}
\hline \multicolumn{2}{c|}{ Rice } & \multicolumn{2}{c}{ Maize } & \multicolumn{2}{c}{ Wheat } \\
\hline Variety & Area (\%) & Variety & Area (\%) & Variety & Area (\%) \\
\hline Radha-12 & 40 & Hybrid & 80 & Gautam & 38 \\
Radha-17 & 8 & Rampur Composite & 20 & NL 297 & 60 \\
Radha-8 & 10 & & & Traditional & 2 \\
Indian varieties & 35 & & & & \\
Kanchhi Masuli & 5 & & & & 100 \\
Traditional & 2 & Total & 100 & Total & \\
\hline Total & 100 & & & & \\
\hline
\end{tabular}




\section{Central hills}

Kavre district was taken as a sample district for central hills. This district has different types of topography such as hills, high hills and river basins where different rice varieties have been adopted by the farmers. Khumal-4 and Taichung varieties of rice were adopted in hills whereas Makwanpur-1, Hardinath-1 and Sabitri were adopted in foot hills and river basins. Khumal-4 was a dominant rice variety which was adopted in 55\% of rice area. Hybrid maize was popular and grown in $60 \%$ of maize area in this district (Table 5). Farmers bought hybrid maize seed mostly from local Agro-Vet dealers who import the seeds from Indian companies. Gautam and WK 1204 were most preferred wheat varieties which were grown in 40 and $35 \%$ area, respectively. Traditional wheat varieties having low yield potential were still adopted in $10 \%$ wheat area.

Table 5. Rice, maize and wheat varieties adopted in the Kavre district, 2009/2010

\begin{tabular}{l|l|l|l|l|l}
\hline \multicolumn{2}{c|}{ Rice } & \multicolumn{2}{c}{ Maize } & \multicolumn{2}{c}{ Wheat } \\
\hline Variety & Area (\%) & Variety & Area (\%) & Variety & Area (\%) \\
\hline Khumal-4 & 55 & Hybrid maize & 60 & Gautam & 40 \\
Makwanpur-1 & 25 & Rampur Composite & 10 & WK 1204 & 35 \\
Hardinath-1 & 3 & Deuti & 15 & Pasang Lhamu & 10 \\
Taichung & 10 & Manakamana-3 & 5 & RR 21 & 2 \\
Sabitri & 2 & Arun -2 & 5 & Annapurna-3 & 3 \\
Traditional & 5 & Traditional & 5 & Traditional (Mudule) & 10 \\
\hline Total & 100 & Total & 100 & Total & 100 \\
\hline
\end{tabular}

\section{Central Terai}

In Bara district of central Terai, the Indian rice variety, Sona Masuli had dominated other rice varieties. Due to high yielding, good taste and good market demand, this variety had covered about $85 \%$ of the total rice area in main rice season. Despite susceptibility to sheath blight disease, farmers were not willing to leave this variety as they lacked substitute of it. Recently, Sworna Sub-1, as an alternative variety of Sona Masuli had been released by NARC after several years of collaborative research with IRRI (NARC 2012). Sworna Sub-1 had similar yield potential and grain quality with Sona Masuli, and also, its submergence tolerant character had been advantageous. Among other rice varieties, Hardinath-1, Sabitri and some hybrid rice varieties had been adopted in the rest of the area.

Hybrid maize varieties had largely dominated other maize varieties mainly due to their higher yield and demand of feed industries. Bara district was already known for maize production and in recent years, Government of Nepal had implemented maize mission program by giving various support to hybrid maize farmers. About 95\% of maize area was covered by hybrid varieties in the district. The hybrid maize grains were largely imported to Nepal for poultry feed industry. It was reported that maize mission program had increased the production and reduced maize import by at least $10 \%$ by the respondents. Regarding wheat varieties, Gautam, BL 1022 and NL 297 were equally adopted in the district (Table 6).

Table 6. Rice, maize and wheat varieties adopted in Bara district, 2009/2010

\begin{tabular}{l|c|c|c|c|c}
\hline \multicolumn{2}{c|}{ Rice } & \multicolumn{2}{c}{ Maize } & \multicolumn{2}{c}{ Wheat } \\
\hline Variety & Area (\%) & Variety & Area (\%) & Variety & Area (\%) \\
\hline Sona Masuli (Indian) & 85 & Hybrid & 95 & Gautam & 30 \\
Hardinath-1 & 8 & Rampur Composite & 3 & BL 1022 & 30 \\
Sabitri & 5 & Arun-2 & 2 & NL 297 & 30 \\
Hybrid & 2 & & & BL 1135 & 5 \\
& & & & Bhrikuti & 5 \\
\hline Total & 100 & Total & 100 & Total & 100 \\
\hline
\end{tabular}




\section{Western hills}

Parbat district was taken as a representative site of western hills for the adoption study. Khumal-8, released in 2007, was the most preferred variety among the improved rice varieties in western hills. Khumal-8 and Makwanpur- 1 were adopted in $30 \%$ and $20 \%$ of rice area, respectively. About $36 \%$ rice area was covered by traditional rice varieties. Among maize varieties, Manakamana-1, and Arun-2 were most preferred varieties and adopted in 30\% and 25\% maize area, respectively. Gautam, released in 2004, was the most preferred wheat variety and adopted in 50\% wheat area whilst WK 1204, released in 2007, was adopted in $25 \%$ of the area (Table 7).

Table 7. Rice, maize and wheat varieties adopted in Parbat district, 2009/2010

\begin{tabular}{l|c|l|c|c|c}
\hline \multicolumn{2}{c|}{ Rice } & \multicolumn{2}{c}{ Maize } & \multicolumn{2}{c}{ Wheat } \\
\hline Variety & Area (\%) & Variety & Area (\%) & Variety & Area (\%) \\
\hline Khumal-8 & 30 & Manakamana-1 & 30 & Gautam & 50 \\
Makwanpur-1 & 20 & Arun-2 & 25 & WK 1204 & 25 \\
Khumal-4 & 5 & Arun-1 & 10 & BL 1473 & 10 \\
Loktantra & 5 & Manakamana-2 & 5 & NL 297 & 10 \\
Machhapuchhre & 2 & Manakamana-3 & 5 & RR 21 & 5 \\
Biramful & 3 & Deuti & 3 & & \\
Traditional & 35 & Hybrid & 2 & & \\
& & Traditional & 20 & Total & 100 \\
\hline Total & 100 & Total & 100 & & \\
\hline
\end{tabular}

\section{Western Terai}

In Rupandehi district of western Terai, Indian rice varieties were dominant which were adopted in $75 \%$ of rice area. Nepal's rice varieties, Radha- 4 and Sabitri were adopted in $15 \%$ and $10 \%$ of rice area, respectively. Hybrid maize and Arun-2 were equally popular and each covered in $40 \%$ of maize area. Among wheat varieties, Gautam and NL 297 were adopted in 35\% and $30 \%$ of wheat area. Bhrikuti, released in 1994 was adopted in 20 percent wheat area whilst Vijaya, released in 2011, was getting popular and adopted in 5\% area (Table 8).

Table 8. Rice, maize and wheat varieties adopted in Rupandehi district, 2009/2010

\begin{tabular}{|c|c|c|c|c|c|}
\hline \multicolumn{2}{|c|}{ Rice } & \multicolumn{2}{|l|}{ Maize } & \multicolumn{2}{|c|}{ Wheat } \\
\hline Variety & Area (\%) & Variety & Area (\%) & Variety & Area (\%) \\
\hline Radha-4 & 15 & Hybrid & 40 & Gautam & 35 \\
\hline Sabitri & 10 & Arun-2 & 40 & NL 297 & 30 \\
\hline Indian varieties & & Rampur Composite & 5 & Bhrikuti & 20 \\
\hline Gorakh Nath & 30 & Traditional & 15 & Vijaya & 5 \\
\hline Sambha Masuli & 20 & & & NL 971 & 2 \\
\hline Golden & 10 & & & NL 1073 & 5 \\
\hline Sarju 52 & 5 & & & BL 1473 & 3 \\
\hline Loknath & 5 & & & & \\
\hline Traditional & 5 & & & & \\
\hline Total & 100 & Total & 100 & Total & 100 \\
\hline
\end{tabular}




\section{Mid western hills}

Dailekh district of mid western hills had mostly Nepalese cereal varieties in adoption. Khumal-4 was a dominant rice variety in 35\% of rice area whilst Deuti was most popular maize variety with adoption of $55 \%$ of maize area. WK 1204 was most preferred wheat variety with adoption of $60 \%$ of wheat area (Table 9 ). The adoption rate of Deuti and WK 1204 were faster as they were spread in short time period after release in 2006 and 2007 respectively.

Table 9. Rice, maize and wheat varieties adopted in Dailekh district, 2009/2010

\begin{tabular}{|c|c|c|c|c|c|}
\hline \multicolumn{2}{|c|}{ Rice } & \multicolumn{2}{|c|}{ Maize } & \multicolumn{2}{|c|}{ Wheat } \\
\hline Variety & Area (\%) & Variety & Area (\%) & Variety & Area (\%) \\
\hline Khumal-4 & 35 & Deuti & 55 & WK 1204 & 60 \\
\hline Hardinath-1 & 15 & Arun-2 & 10 & Gautam & 10 \\
\hline Khumal-11 & 5 & Manakamana-1 & 10 & BL 1473 & 5 \\
\hline Loktantra & 10 & Manakamana-3 & 10 & RR 21 & 10 \\
\hline Radha-4 & 10 & Shitala & 5 & Traditional & 15 \\
\hline Radha-7 & 10 & Traditional & 10 & & \\
\hline Traditional & 15 & & & & \\
\hline Total & 100 & Total & 100 & Total & 100 \\
\hline
\end{tabular}

\section{Mid western Terai}

Banke district of mid western Terai had large area of Radha-4 rice variety, which was adopted in 70\% rice area. Gauchan and Pandey (2011) reported that Radha4 and Janaki were most adopted varieties in Banke district, where this study found similar information
(Table 10). Indian rice varieties including hybrids were also adopted in $15 \%$ rice area. Rampur composite was most preferred maize variety which was adopted in 55\% maize area. Indian hybrid maize and Arun-2 were equally popular and each had covered $20 \%$ maize area. Similarly, Gautam and NL 297 were equally preferred and each had covered in $40 \%$ wheat area.

Table 10. Rice, maize and wheat varieties adopted in Banke district, 2009/2010

\begin{tabular}{l|c|c|c|c|c}
\hline \multicolumn{2}{|c|}{ Rice } & \multicolumn{2}{c}{ Maize } & \multicolumn{2}{c}{ Wheat } \\
\hline Variety & Area (\%) & Variety & Area (\%) & Variety & Area (\%) \\
\hline Radha-4 & 70 & Rampur composite & 55 & Gautam & 40 \\
Janaki & 10 & Hybrid & 20 & NL 297 & 40 \\
Hardinath-1 & 3 & Arun-2 & 20 & BL 1022 & 10 \\
Hybrid (Indian) & 10 & Traditional & 5 & UP 262 & 5 \\
Indian varieties & 5 & & Bhrikuti & 3 \\
Traditional & 2 & & RR-21 & 2 \\
\hline Total & 100 & Total & 100 & Total & 100 \\
\hline
\end{tabular}

\section{Far western hills}

Doti district of far western hills had less adoption of modern rice varieties as compared to other hill districts. Khumal-4, Radha-12 and Hardinath-1 had covered 50\% rice area whilst traditional rice cultivars had covered rest of the area. The extension staff reported that there was high demand of drought tolerant rice varieties which were suitable for high hills. Regional Agricultural Research Station, Nepalgunj had developed some drought tolerant varieties for Terai and hills. These 
varieties did not perform well in the hills of Doti that may be due to higher altitude with cold climate. Deuti was most adopted maize variety with coverage in $20 \%$ maize area. About 35\% wheat area was covered by traditional wheat cultivars which were two types, namely Punte and Dabda in local language. NL 297 and BL 1022 were getting popular each of which had covered $20 \%$ wheat area (Table 11 ).

Table 11. Rice, maize and wheat varieties adopted in Doti district, 2009/2010

\begin{tabular}{|c|c|c|c|c|c|}
\hline \multicolumn{2}{|c|}{ Rice } & \multicolumn{2}{|l|}{ Maize } & \multicolumn{2}{|l|}{ Wheat } \\
\hline Variety & Area (\%) & Variety & Area (\%) & Variety & Area (\%) \\
\hline Khumal-4 & 25 & Deuti & 20 & NL 297 & 20 \\
\hline Radha-4 & 12 & Manakamana-3 & 10 & BL 1022 & 20 \\
\hline Hardinath-1 & 10 & Manakamana-2 & 10 & WK 1204 & 10 \\
\hline Chaite-1 & 4 & Arun-2 & 10 & Gautam & 15 \\
\hline \multirow[t]{2}{*}{ Traditional } & 50 & Rampur composite & 10 & Traditional- Punte & 25 \\
\hline & & Traditional (60 days) & 40 & Traditional-Dabda & 10 \\
\hline Total & 100 & Total & 100 & Total & 100 \\
\hline
\end{tabular}

\section{Far western Terai}

In Kailali district of far western region, Indian rice variety, Sarju-52, was most popular and adopted in $60 \%$ rice area. For maize, Rampur Composite was adopted in half of the maize area whilst Arun-2 was adopted in $45 \%$ area. Indian maize hybrid was adopted only in 5\% maize area which was the least adoption of hybrid maize among the Terai districts. For wheat, NL 297 had covered in 40\% wheat area whilst each of Bhrikuti and Gautam had covered one fourth of the area. Indian wheat varieties were found in $10 \%$ wheat area (Table 12).

Table 12. Rice, maize and wheat varieties adopted in Kailali district, 2009/2010

\begin{tabular}{l|c|c|c|c|c}
\hline \multicolumn{2}{c|}{ Rice } & \multicolumn{2}{c}{ Maize } & \multicolumn{2}{c}{ Wheat } \\
\hline Variety & Area (\%) & Variety & Area (\%) & Variety & Area (\%) \\
\hline Sarju-52 & 60 & Rampur composite & 50 & NL 297 & 40 \\
Radha-4 & 8 & Arun-2 & 45 & Bhrikuti & 25 \\
Hardinath-1 & 10 & Hybrid maize & 5 & Gautam & 25 \\
Sabitri & 8 & & & & 10 \\
Samba masuli & 8 & & & & \\
Loktantra & 1 & & & & 100 \\
Traditional & 5 & & 100 & Total & \\
\hline Total & 100 & Total & & & \\
\hline
\end{tabular}

The variety development cost was higher in maize as compared to rice and wheat. During the last ten years, variety development cost was Rs. 38.1 million in maize, 15.8 million in wheat and 14.6 million in rice, at 2000/01 price. The variety development cost of maize, wheat and rice was, 46,34 , and $24 \%$ of their individual research cost, respectively. Human resource in research was involved as 35 FTE in rice, 28 FTE in wheat, and 18 FTE in maize. Of the total FTE researchers, about 8 FTE was involved in breeding or variety development in each of rice, wheat and maize. However, the investment for variety development in maize was about two and half times more than that of rice or wheat during the ten years of observation. 
H.K. Shrestha et al./Variety Development.

The overall adoption of modern varieties of rice was poor as compared to those of maize and wheat in the country. The adoption area of modern rice variety in hills ranged from $50 \%$ (Doti) to 95 (Kavre) of total rice area in main season. In case of wheat, it ranges from $65 \%$ (Doti) to $95 \%$ (Dhankuta) of total wheat area whilst in maize, it ranges from $60 \%$ (Doti) to $95 \%$ (Kavre) of maize area. It is comparable with national level data for hills which shows that the improved variety of rice, wheat and maize were adopted in 83\%, 94\% and 87\% of their area. The adoption area of modern rice variety in Terai ranges from 95 percent (Rupandehi) to 100 percent (Bara) of rice area in normal season. In case of wheat, it ranges from 98 (Sunsari) to 100\% (Bara, Rupandehi, Banke, and Kailali) whilst in maize, it ranges from 85 (Rupandehi) to 100\% area (Sunsari, Bara, Kailali). It is also comparable with national level data showing that the improved variety of rice, wheat and maize were adopted in $89 \%, 100 \%$ and $99 \%$ of their area in Terai (MoAC 2010). Indian rice varieties and Indian maize hybrids were common in Terai region particularly in Bara district that represents central Terai. Nepal's research system still needs to develop high yielding modern varieties which can be easily adopted in farmers' condition. Adoption percent of improved rice varieties was smaller despite the larger number of FTE researchers was involved in this crop, however reverse is the case in wheat and maize.

\section{References}

Bellon, M., and J.E. Taylor. 1993. Folk soil taxonomy and partial adoption of new seed varieties. Economic Development and Cultural Change. 41: 763-786.

Doss, C.R. 2006. Analyzing technology adoption using micro-studies: limitations, challenges, and opportunities for improvement. Agricultural Economics. 34: 207-219.
Feder, G., R.E. Just and D. Zilberman. 1985. Adoption of agricultural innovations in developing countries: a survey. Economic Development and Cultural Change. 33: 255-298.

Gauchan, D. and S. Pandey. 2011. Socio-economic analyses of farmer livelihoods, modern variety adoption and economics of rice production in stress-prone rainfed areas of Nepal. IRRI, Phillipines.

MoAC. 2010. Statistical Information on Nepalese Agriculture. Ministry of Agriculture and Cooperatives (MoAC), Government of Nepal, Singh Durbar, Kathmandu, Nepal.

Morris, M.L., H.J. Dubin and T. Pokhrel. 1994. Returns to wheat breeding research in Nepal. Agricultural Economics, 10: 269-282.

NARC. 2012. Released and Registered Crop Varieties in Nepal (1960-2012). Nepal Agricultural Research Council. Kathmandu, Nepal.

Pardey, P.G. and N.M. Beintema. 2001. Slow magic: agricultural research a century after Mendel. International Food Policy Research Institute. Washington DC.

Rahija, M., H.K. Shrestha, G.J. Stads and R.B. Bhujel. 2011. Recent development in public agricultural research. Agricultural science and technology indicators: Nepal. International Food Policy Research Institute. Washington DC, 6 p.

Stads, G.J. and H.K. Shrestha. 2006. Agricultural science and technology indicators: Nepal. ASTI Country Brief No. 37. International Food Policy Research Institute. Washington DC, $12 \mathrm{p}$.

Timsina, K.P., H.B. Bista, D. Gauchan, B. Sapkota, Y.N. Ghimire, K.P. Shrestha and B. Shrestha. 2012. Adoption of rice varieties in Terai region of Nepal. In: Proceedings of the $10^{\text {th }}$ National Outreach Workshop, 27-28, February, 2012. RARS, Lumle, Kaski.

Witcombe, J., K.K. Lal and K.D. Joshi. 2009. Scoping study on adoption of rice varieities from client oriented breeding in the Nepal rice innovation system. CAZS natural resources, Bangor University, UK. 
Nepal Journal of Science and Technology Vol. 13, No. 1 (2012) 